\title{
The agricultural heritage of Lampedusa (Pelagie Archipelago, South Italy) and its key role for cultivar and wildlife conservation
}

\author{
Tommaso La Mantia, ${ }^{1}$ Francesco Carimi, ${ }^{2}$ Rosario Di Lorenzo, ${ }^{1}$ Salvatore Pasta' \\ ${ }^{1}$ Dipartimento di Colture Arboree, Università di Palermo; ${ }^{2}$ Istituto di Genetica Vegetale, UOS di \\ Palermo, Consiglio Nazionale delle Ricerche, Italy
}

\begin{abstract}
As occurred on many other small Mediterranean islands, agricultural activity at Lampedusa (Strait of Sicily) underwent a very strong decline in terms of surface area during the second half of the last century. In particular, cereal crops have ceased and horticulture is disap-
\end{abstract}

Correspondence: Tommaso La Mantia, Dipartimento DEMETRA, Università di Palermo, viale delle Scienze, Ed. 4, Ingr. H, 90128 Palermo, Italy. Tel. +39.091.23862201 - Fax: +39.091.23861211.

E-mail: tommasolamantia@unipa.it

Key words: biodiversity, grapevine, landscape, Sicily, small island, variety.

Acknowledgements: this research was funded by Regione Siciliana, Assessorato Risorse Agricole e Alimentari - Dipartimento Interventi Infrastrutturali, Area Studi e Programmazione, Project "Analisi dei sistemi seminaturali e degli agroecosistemi nei sistemi insulari mediterranei: Isola di Lampedusa e pantani di Vendicari" and the project "Risorse Genetiche Vegetali - Coltura in vitro per la conservazione del germoplasma vegetale siciliano minacciato da erosione genetica". Field investigation started during the drafting of the chapters on "Floristic, vegetational and agro-forestry aspects" of "Isole Pelagie -Management Plan" (POR 1999.IT.16.1.P0.011/ 1.11/11.2.9/0304) commissioned to DCA by Legambiente-Comitato Regionale Siciliano. We would like to thank Dario Caltabellotta, Antonino Drago, Fabio Guaitoli and Gabriella Matranga of the Sicily Region; Angelo Dimarca, Vincenzo Billeci, Salvatore Livreri Console, Giuseppina Nicolini, Giuseppe Maraventano and Gerry Sorrentino of Legambiente; the farmers of Lampedusa and Linosa (who also provided valuable information on the past agricultural practices at Lampedusa): Pino Bartòlo, Salvatore Bartòlo, Antonino Bono, Salvatore Bono, Concetta De Battista, Fedele Giardina, Totò La Russa, Salvatore La Russa, Vincenzo La Russa, Salvatore Maltese, Giuseppe Palmeri, Giacomo Sorrentino, Gaetano Taranto, Pasquale Tonnicchia. We also acknowledge Damiano Sferlazzo for providing climatic data, Antonino Taranto for historical information, Prof. Paolo Roggero for valuable advice and comments on the first draft of the manuscript and two anonymous referees whose useful suggestions improved the final version of this paper. Work submitted to the 3rd International Congress on "Mountain and steep slope viticulture" (Castiglione di Sicilia, Italy, May 12-14, 2010).

Received for publication: 10 September 2010.

Accepted for publication: 26 March 2011.

CC Copyright T. La Mantia et al., 2011

Licensee PAGEPress, Italy

Italian Journal of Agronomy 2011; 6:e17

doi:10.4081/ija.2011.e17

This work is licensed under a Creative Commons Attribution NonCommercial 3.0 License (CC BY-NC 3.0). pearing, while vineyards still occupy a reduced area but are quickly vanishing and currently survive thanks to a small number of old farmers. Here are presented the results of a research carried out by interviewing seven farmers in order to study not only the techniques and the germplasm used in local viticulture, but also the final use of grapes and an evaluation on the connection between traditional farming and agro-ecosystems plant species-richness. Vines were grown for wine, to produce fresh and sun-dried grapes, or to preserve them in alcohol. Several names of the local varieties suggest that they might have been introduced in Lampedusa from the neighbouring territories: being fishermen and farmers at the same time, local people had trade relationships with other Mediterranean areas such as Tunisia, Malta and Southern Italy. Furthermore, local farming plays a key role in plant conservation. In fact, the disappearance of agricultural systems is leading to the extinction of 43 plant species, some of them considered rare not only on the local level, but also on the regional and national one. Because of the small size of farmland and its fragmentation, local agriculture cannot be supported by the European Community. Therefore, in order to safeguard local viticulture, special systems of assistance and new managing policies - focused on rural development plans and showing which concrete actions are necessary and feasible to protect the agroecosystems - are needed.

\section{Introduction}

As already occurred in several other territorial contexts of the Mediterranean Basin, southern Italy and islands in particular, the agricultural areas that have survived play a crucial role not only for the preservation of dozens of cultivars, often the result of centuries of selective choices by local farmers (Hammer et al., 1990, 1996, 1997, 1999; Hammer and Perrino, 1995; Laghetti et al., 1996, 1998a-b, 2002; Hammer and Laghetti, 2006), but more extensively in order to maintain the overall agrobiodiversity (Spahillari et al., 1999) and plant biodiversity. In fact, it has already been verified that such extensive crops and farming areas harbour a high number of plant species (Rühl, 2003, 2007), and how their disappearance and rarefaction have adverse consequences for many annual plants that have the opportunity to exploit the recently cultivated and uncultivated lands (Lampedusa: Pasta, 2001; Marettimo: Gianguzzi et al., 2006; Ustica: Pasta et al., 2007a).

The island systems are considered particularly vulnerable to degradation (Millennium Ecosystem Assessment, 2005). Therefore, in the last decades, much attention has been paid to the loss of traditional knowledge and biodiversity in small islands (UNEP, 1998).

Lampedusa's case is emblematic of - and very similar to - that of many other small Mediterranean islands, where a close connection between agriculture and biodiversity at different levels (landscape, specific, genetic) can be observed.

In the past, Lampedusa was almost self-sufficient in terms of crop 
production, but nowadays local inhabitants import most of the plant products from Sicily. However, in few small areas of the island there still are cultivated fields, mainly vineyards and orchards. Fruit trees are uncommon and only some species are still cultivated: fig, pomegranate, peach, apricot, carob and Indian fig (the last mainly for animal feed; Hammer and Laghetti, 2006).

Notwithstanding, the agriculture of the nearby Linosa island has been studied rather thoroughly (Hammer et al., 1997; Laghetti et al., 1998b) and taking into account some studies on the horticultural germplasm of Lampedusa (Laghetti et al., 1996), available information on the viticulture and farming systems on both the Pelagian Islands are scarce; even the historical documents lack of any evidence concerning this topic (Pasta and La Mantia, 2003).

As for the herbaceous species still cultivated on Lampedusa, there are only a few landraces of pulses (broad beans, lentils and peas), vegetables (peppers and vegetables marrows) and aromatic plants (oregano and rue) (Hammer and Laghetti, 2006). Other cultivated plants do not come from locally produced seeds.

Among the species still cultivated in Lampedusa the only noteworthy crop is the grapevine. The survey carried out during this research has established the peculiarity of the viticulture of Lampedusa, particularly that of the utilized germplasm, but also the extreme fragility of the agro-ecosystem linked to this land use.

\section{Materials and Methods}

\section{Environmental characteristics}

Lampedusa is located $205 \mathrm{~km}$ from the Sicilian coast and $113 \mathrm{~km}$ from the African one, and it looks like a triangular plateau which northern coast forms an almost continuous steep cliff and which slopes gently decline southwards, where the coastline shows a very uneven appearance due to the presence of several canyons. Local agriculture has developed inside these canyons thanks to the make up of dry stonewalls. Lampedusa is subject to a climate ranging from the semiarid Mediterranean of Southern Sicily to the arid of North Africa and, according to the classification of Rivas-Martínez (2004), should be referred to the infra-Mediterranean type (Sferlazzo, 2009). Local wind regime strongly influences the environment and, thus, agriculture, as it has been already underlined by Calcara (1846). Therefore, agriculture was measured with these limits, with a very irregular and low rainfall (less than $320 \mathrm{~mm} / \mathrm{yr}$ ), and a rather wide temperature range (minimum winter values fluctuate between 9 and $14^{\circ} \mathrm{C}$, maximum summer ones between 24 and $30^{\circ} \mathrm{C}$ ). Therefore, significant extensions of relatively deep brown soils can be found exclusively in areas protected from wind erosion, in particular within valleys.

\section{Survey on viticulture}

The field investigation was carried out by interviewing local farmers through a standard questionnaire containing the following data: date of the interview, name of the interviewers, name of the interviewed; GPS coordinates of the plants collected; location, altitude (m a.s.l.), slope $\left({ }^{\circ}\right)$, aspect; name of still or previously cultivated varieties, origin and year of introduction (if known), characteristics (colour, shape, size, etc.) of the grapes, use of the grapes, cultivation techniques, number of individuals; notes.

Up to now (spring 2010) seven of the eleven farmers who still cultivate vines have been interviewed; thus, the data shown here may be considered representative of the whole island.

\section{Species richness census}

The data presented here come from field relevés carried out by the authors during the spring season of 2009 and 2010, from the most recent contributions to the knowledge of Lampedusa's vascular flora (Bartolo et al., 1990; La Mantia et al., 2009) and from the floristic and phytosociological relevés (Braun-Blanquet, 1964) carried out during the past 15 years, while investigating the natural and agricultural territory of Lampedusa in order to write the management plan for the Pelagie Islands (La Mantia et al., 2009) and to evaluate the diffusion and the degree of threat of native plant life (La Mela Veca et al. 2003; La Mela Veca and Pasta, 2006). Moreover, the effect of the decreasing grazing pressure on scrubland and grassland (Pasta and La Mantia, 2006, Pasta et al., 2007b) and the effect of different techniques of reforestation on the dynamism of local vegetation (Pasta and La Mantia, 2001) were taken into consideration.

\section{Results and Discussion}

\section{Viticulture}

In Lampedusa island, this crop characterizes only a few hectares, approximately 30 according to our estimates, while approximately 10 ha have been recently abandoned according to Ravanello (2007), who describes five varieties still cultivated on the island: Moscato d'Alessandria or Zibibbo, white Moscato, Catarratto, Insolia, Nocera delle Isole or Nocerone (dark grape). Despite the reduced area, local viticulture still has an extraordinary interest due to the variety richness. In fact, through the interviews to local farmers 18 varieties have been found: Bertuccio, Calabrisi, Catarratto, Catarratto Nero, Funciachiatta, Funciachiatta Rosella, Gallipoli Bianca, Gallipoli Nera, Inzolia, Inzolia Maltese, Minna di Vacca, Nave, Nivureddu, Paradiso, Pizzutella Bianca, Sfaghesina, Squagghiammucca, Zibibbo; some of them appear to be new to the Sicilian variety heritage (Carimi et al., 2010). Only three varieties, i.e. Nivureddu, Catarratto and Catarratto Nero are common in Lampedusa, while four of them are uncommon (Zibibbo, Inzolia, Inzolia Maltese) and 13 even rare (Bertuccio, Calabrisi, Funciachiatta, Funciachiatta Rosella, Gallipoli Bianca, Gallipoli Nera, Minna di Vacca, Nave, Nivureddu, Paradiso, Pizzutella Bianca, Sfaghesina and Squagghiammucca). Several of them are now present with very few individuals; their past use is probably due to previous economic links between the inhabitants of Lampedusa and Tunisia or other territories where they had established trade relations along the Adriatic coast. All this patrimony is disappearing without leaving its mark in history. This risk is already going on: in his recent paper, Ravanello (2007) only mentioned four white and one black grape varieties, neglecting many other varieties. Along with the local varieties, also traditional uses connected to their peculiarities tend to disappear. Only one farmer, for example, still cultivated the variety called Funciachiatta, of Tunisian origin, wich was used to produce grapes in alcohol.

A very interesting feature is that local grapevines are not grafted and show no damage caused by Phylloxera, although damages have been reported in the past (Ravanello, 2007). Concerning pathogens, the local high levels of air humidity force vineyard growers to use traditional treatments such as lime and sulfur to prevent powdery mildew.

Viticulture becomes important even for landscaping purposes; the abandonment of vineyards, in fact, often is followed by the degradation of these small plots of land that become landfills or are invaded by xenophytes (Pasta and La Mantia, 2008). Connected to these phenomena is land degradation: when land is no longer managed and preserved by the maintenance of dry stonewalls, it rapidly undergoes erosion processes.

Along with the abandonment of the vineyards, also local agronomic techniques disappear; for centuries these techniques (e.g. cultivating 
plants in holes in order to reduce water loss) allowed the vines to live and produce under difficult climatic conditions. As regards local climate, during last years rainfall events became more and more irregular and intense (year 2007: 174,51 mm in 62 days; year 2008: 171,45 mm in 51 days; year 2010: 493,06 in 69 days: http:/www.tutiempo.net/clima/ Italia/T.html); for example, the autumn-winter 2009-2010 rainfaill was almost entirely concentrated in just one day (i.e. about $216 \mathrm{~mm}$ from midnight of September 22 to midnight of September 23, 2009), causing severe damage to many agricultural areas. The soil management techniques of are greatly simplified; in fact, only few treatments are performed in order to prevent powdery mildew and downy mildew with sulfur and copper-based products. Moreover, soil management is implemented performing a few annual working with rotary tiller. Usually, farmers do not use herbicides and this has a great impact on biodiversity.

\section{The key role of agriculture in maintaining local plant biodiversity}

The existence of agro-pastoral practices play a key role not only for the preservation and recovery of local cultivars but also for maintaining the plant biodiversity on the island, which have experienced a strong numerical regression of the number of species present. In fact, from the historical data of the first floristic censuses (Gussone, 1832-1834, 1839) up to the present day, there are almost 150 entities that are extinct on Lampedusa, of which almost one third (43) were typical of local agro-ecosystems (Table 1).

Among the above mentioned taxa, Silene behen and $S$. muscipula figure in the regional red lists compiled by Conti et al. (1997), being indicated respectively as VU (vulnerable) and EN (endangered), while Vicia monantha subsp. calcarata and Carthamus lanatus subsp. baeti-

Table 1. Overview on the extinct vascular plants of Lampedusa.

\begin{tabular}{|c|c|c|}
\hline Family & Taxon & Main habitat \\
\hline \multirow[t]{3}{*}{ Apiaceae (3) } & Ammi majus L. & Cereal crops, fallows \\
\hline & Ammoides pusilla (Brot.) Breistr. & Cereal crops, fallows \\
\hline & Bifora testiculata (L.) Roth & Cereal crops \\
\hline Asteraceae (3) & $\begin{array}{l}\text { Anthemis arvensis L. subsp. arvensis } \\
\text { Calendula arvensis L. subsp. arvensis } \\
\text { Carthamus lanatus L. subsp. baeticus (Boiss. \& Reuter) Nyman }\end{array}$ & $\begin{array}{l}\text { Cereal crops, fallows } \\
\text { Cereal crops, fallows } \\
\text { Fallows, grazed grasslands }\end{array}$ \\
\hline Brassicaceae (2) & Brassica tournefortii Gouan & Horticulture, fallows \\
\hline & Raphanus sativus L. & Horticulture, fallows \\
\hline Caryophyllaceae (3) & $\begin{array}{l}\text { Silene behen } \mathrm{L} . \\
\text { Silene gallica } \mathrm{L} . \\
\text { Silene muscipula } \mathrm{L} .\end{array}$ & $\begin{array}{l}\text { Horticulture, fallows } \\
\text { Horticulture, cereal crops, fallows } \\
\text { Horticulture, fallows }\end{array}$ \\
\hline Convolvulaceae (1) & Convolvulus tricolor L. subsp. tricolor & Horticulture, cereal crops, fallows \\
\hline Euphorbiaceae (1) & Euphorbia terracina L. & Fallows \\
\hline Fabaceae (14) & $\begin{array}{l}\text { Lathyrus ochrus (L.) DC. } \\
\text { Medicago italica (Mill.) Fiori subsp. italica } \\
\text { Melilotus elegans Ser. } \\
\text { Melilotus indicus All. } \\
\text { Trifolium cherleri L. } \\
\text { Trifolium glomeratum L. } \\
\text { Trifolium nigrescens Viv. subsp. nigrescens } \\
\text { Trifolium stellatum L. } \\
\text { Trifolium suffocatum L. } \\
\text { Trifolium tomentosum L. } \\
\text { Vicia angustifolia L. } \\
\text { Vicia benghalensis L. } \\
\text { Vicia monantha Retz. subsp. calcarata (Desf.) Romero Zarco } \\
\text { Vicia peregrina L. }\end{array}$ & $\begin{array}{l}\text { Horticulture, fallows } \\
\text { Horticulture, fallows } \\
\text { Fallows } \\
\text { Fallows } \\
\text { Fallows } \\
\text { Fallows } \\
\text { Fallows } \\
\text { Fallows } \\
\text { Fallows } \\
\text { Fallows } \\
\text { Fallows } \\
\text { Fallows } \\
\text { Fallows } \\
\text { Fallows }\end{array}$ \\
\hline Fumariaceae (2) & $\begin{array}{l}\text { Fumaria densiflora } \text { DC. } \\
\text { Hypecoum procumbens L. }\end{array}$ & $\begin{array}{l}\text { Horticulture } \\
\text { Horticulture, fallows }\end{array}$ \\
\hline Malvaceae (1) & Malva sylvestris L. & Fallows \\
\hline Orobanchaceae (1) & Orobanche crenata Forssk. & Horticulture \\
\hline Poaceae $(9)$ & $\begin{array}{l}\text { Bromus diandrus Roth } \\
\text { Bromus tectorum L. } \\
\text { Catapodium hemipoa (Sprengel) Lainz subsp. hemipoa } \\
\text { Cynosurus echinatus L. } \\
\text { Dasypyrum villosum (L.) Borbás } \\
\text { Phalaris aquatica L. } \\
\text { Phalaris brachystachys Link. } \\
\text { Vulpia ciliata Dumort. } \\
\text { Vulpia ligustica } \text { (All.) Link }\end{array}$ & $\begin{array}{l}\text { Fallows } \\
\text { Fallows } \\
\text { Fallows } \\
\text { Fallows, grazed grasslands } \\
\text { Fallows } \\
\text { Fallows } \\
\text { Cereal crops, fallows } \\
\text { Fallows } \\
\text { Fallows }\end{array}$ \\
\hline Resedaceae (1) & Reseda luteola L. & Fallows \\
\hline Scrophulariaceae (1) & Veronica arvensis $\mathrm{L}$. & Cereal crops, orticulture, olive groves, etc. \\
\hline Urticaceae (1) & Urtica pilulifera L. & Grazed grasslands, fallows \\
\hline
\end{tabular}


cus are extremely rare and in decline at a regional level (Raimondo et al., 1994).

Moreover, taking into consideration all the up-to-date information obtained through the recent check of local vascular flora (La Mantia et al., 2009), over 100 of the approximately 450 taxa still present on the island are exclusively or preferentially linked to the last patches of the local agro-pastoral landscape, surviving in horticultural crops, in terrace cultivations destined for cereal and/or in uncultivated pastures. Some of them, unprotected by any national law or direct protective measure - because they do not fall within the natural reserve Isola $d i$ Lampedusa, or within the Site of Community Importance ITA0040002 Isola di Lampedusa e Lampione - are now close to extinction, an event which would result in the disappearance not only at a local, but also provincial or even regional level. Among the most endangered plants with a certain phytogeographic value or considered extremely rare and threatened with extinction that are worth mentioning are Eruca sativa Mill. subsp. longirostris (Uechtr.) Jahand. \& Maire (as far as we know, Lampedusa's fallows give hospitality to its only Italian population), Marrubium alysson L., where Lampedusa hosts the only known Sicilian population, recently confirmed (Pasta et al., unpublished data) some 50 years after the first finding (Di Martino, 1958), Silene turbinata Guss., Glaucium corniculatum (L.) J.H. Rudolph, close to extinction on a national and regional level, respectively, and Calendula bicolor Raf. Calendula tripterocarpa Rupr., Carduus argyroa Biv. and C. australis L. fil. subsp. marmoratus (Boiss. \& Heldr.) Kazmi, Heliotropium dolosum De Not. and Mantisalca duriaei (Spach) Briq. \& Cavillier. The above mentioned species are quite rare on the Italian territory.

\section{Conclusions}

The ecosystems must have the ability to respond to unexpected change, to remain functional and healthy. There is common agreement on the concept that biodiversity loss and ecosystem degradation put at risk human well-being, now and in the future, and that biodiversity is necessary to keep open options to secure future to human well-being (Mace et al., 2010). Farmer attitudes and social networking are critical for the improvement and preservation of biodiversity in agricultural landscapes. Fast changes in land use, food systems, and livelihoods require social-ecological systems that maintain multiple options open and prepare for future unpredictability. Incentives are crucial if agrobiodiversity is to provide benefits to future generations (Jackson et al., 2010).

Local participation remains widely seen as a central condition for sustainable management of ecosystems landscapes.

The decision No. IX/1 In-depth review of the programme of work on agricultural biodiversity of the Convention on Biological Diversity (CBD, www.biodiv.org) on the 9th Meeting of the Conference of the Parties (COP 9) held at Bonn, Germany, from 19 to 30 May 2008, explicitly recognizes the key-role of local communities, including farmers and livestock keepers, in the conservation and sustainable use of agricultural biodiversity and underlines the importance of improving the policy environment to support local-level management of agricultural biodiversity (http://www.cbd.int/decision/cop/?id=11644).

However, the agriculture on the island of Lampedusa actually does not nor can it receive any support because of the small size and their fragmentation. Given the ceased grain cultivation (barley was still cultivated few years ago and wheat some decades before) and the extremely reduced horticulture, viticulture still survives on a few tens of hectares thanks to a few elderly farmers who still practice agriculture. With the intense competition for land use linked to tourism, the survival of farming in general makes viticulture even more precarious. In some cases, the vines are replaced by olive trees, as they require less care and therefore, their cultivation results less expensive. Nevertheless, it is clear the peculiarity of this system: the vines are free of foot, grown in a difficult environment due to the strong drought, ensured a product used to produce wine but also for the direct consumption as a fresh or dried product. More detailed investigation like those having been carried out on other circumsicilian islets (Di Lorenzo and Lo Vetere, 2006) could highlight further peculiarities.

Agro-pastoral activity as a whole ensured the survival of unique habitats, where a high number rare plant and animal species live; many of them are now disappearing due to the elimination of these land use systems: this is true not only for all the above mentioned plants, but also for some birds such as the Greater short-toed lark (Calandrella brachydactyla) (Massa and La Mantia, 2010). The wealth of knowledge and the amount of germplasm that remains today is the legacy of the history of the people of Lampedusa: farmers in the winter and fishermen in the summer that would go to fish for sponge in Tunisia and trade with other areas of the Mediterranean, North Africa, and also Malta, Sicily, and the rest of Italy.

The example of Lampedusa is representative to show how the lack of planning at multiple scales puts agrobiodiversity, human well-being, and ecological systems at risk. The problems of agriculture in Lampedusa are common with other small islands in the Mediterranean basin and for these realities specific measures should be planned and taken in order to help and preserve this heritage. In this regard, the Millennium Ecosystem Assessment (2005), declared The long-term development objectives of islands also need to be considered. Despite physical and natural resource limitations, important consideration will need to be given to integrated planning, social cohesion, increased attention to managing biodiversity (in particular, invasive species), and a strengthening of territorial planning if islands are to become economically, socially, and ecologically resilient and self-sufficient.

\section{References}

Bartolo G., Brullo S., Minissale P., Spampinato G., 1990. Flora e vegetazione dell'isola di Lampedusa. Boll. Accad. Gioenia Sci. Nat., s. 4 , 21 (334)(1988):119-255.

Braun-Blanquet J., 1964. Pflanzensoziologie. Grundzüge der Vegetationskunde Ed. 3. Springer, Wien, Austria.

Calcara P., 1846. Rapporto del viaggio scientifico eseguito nelle isole di Lampedusa, Linosa e Pantellarìa, ed in altri punti della Sicilia. - Il Contemporaneo (Palermo), 7(13):97-99; ibidem, 7 (14):105-108. estr. Stamp. R. Pagano, Palermo, 32 pp.

Carimi F., Mercati F., Abbate L., Sunseri F., 2010. Microsatellite analyses for evaluation of genetic diversity among Sicilian grapevine cultivars. Genet. Resour. Crop Evol. 57:703-719.

Conti F., Manzi A., Pedrotti F., 1997. Liste Rosse Regionali delle Piante d'Italia. W.W.F., Soc. Bot. Ital., Camerino, 139 pp.

Di Lorenzo R., Lo Vetere R., 2006. Aromatic compounds in "Zibibbo" grape bush and VSP trained in Pantelleria island. Preliminar results. Atti su CD-rom del I Congresso Internazionale sulla Viticoltura di Montagna e in Forte Pendenza, St. Vincent, 17-18 marzo 2006, 103.8 pp.

Di Martino A., 1958. Nuovo contributo alla flora inedita delle Isole Pelagie. Lav. Ist. Bot. e Giard. Colon. Palermo 16:84-93.

Gianguzzi L., Scuderi L., Pasta S., 2006. La flora vascolare dell'isola di Marettimo (Arcipelago delle Egadi, Sicilia occidentale): aggiornamento e analisi fitogeografica. Webbia 61:359-402.

Gussone G., 1832-1834. Supplementum ad Florae Siculae Prodromum, quod et specimen florae insularum Siciliae ulteriori adjacentium. Fasciculus secundus. Neapoli, ex Regia Typographia.

Gussone G., 1839. Notizie sulle isole di Linosa, Lampione e Lampedusa, 
e descrizione di una nuova specie di Stapelia che trovasi in questa ultima, lette nell'anno 1832. Atti R. Accad. Sci. Sez. Soc. R. Borbonica (Sez. Bot.) 4:74-97.

Hammer K., Knüpffer H., Perrino P., 1990. A checklist of the South Italian cultivated plants. Kulturpflanze 38:191-310.

Hammer K., Knüpffer H., Xhuveli L., Perrino P., 1996. Estimating genetic erosion in landraces - two case studies. Genet. Resour. Crop Evol. 43:329-336.

Hammer K., Laghetti G., 2006. Small Agricultural Islands and Plant Genetic Resources - Le piccole isole rurali italiane. IGV-CNR Ed., Bari, Italy, pp. X +246 .

Hammer K., Laghetti G., Perrino P., 1997. Proposal to make the island of Linosa (Italy) as a centre for on-farm conservation of plant genetic resources. Genet. Resour. Crop Evol. 44:127-135.

Hammer K., Laghetti G., Perrino P., 1999. A checklist of the cultivated plants of Ustica (Italy). Genet. Resour. Crop Ev. 46: 95-106.

Hammer K., Perrino P., 1995. Plant genetic resources in South Italy and Sicily - studies towards in situ and on farm conservation. Pl. Gen. Res. Newsl. 103:19-23.

Jackson L., van Noordwijk M., Bengtsson J., Foster W., Lipper L., Pulleman M, Said M., Snaddon J., Vodouhe R., 2010. Biodiversity and agricultural sustainagility: from assessment to adaptive management. Curr. Opin. Environ. Sustain. 2:80-87.

La Mantia T., Pasta S., Rühl J., 2009. Quadro conoscitivo e proposte gestionali relative agli aspetti floristici, vegetazionali e agro-forestali. Piano di Gestione "Isole Pelagie" SIC ITA040002 "Isole di Lampedusa e Lampione" e ZPS ITA040013 "Arcipelago delle Pelagie. Area marina e terrestre", $353 \mathrm{pp}$.

La Mela Veca D.S., Pasta S., 2006. Relazione tecnico-scientifica sul "Censimento delle emergenze botaniche della Riserva Naturale Orientata "Isola di Lampedusa" (AG). Ente Gestore LegambienteComitato Regionale Siciliano, Lampedusa, Italy.

La Mela Veca D.S., Pasta S., Sessa K., La Mantia T., 2003. Censimento e tutela delle formazioni vegetali naturali fuori foresta: il caso di Lampedusa (Arcipelago delle Pelagie). It. For. e Mont. 3:191-201.

Laghetti G., Hammer K., Cifarelli S., Branca F., Diederichsen A., Perrino P., 2002. Collection of crop genetic resources in Egadi archipelago and southern Sicily. Plant Genet. Resour. Newsl. 132:39-47.

Laghetti G., Hammer K., Olita G., Perrino P., 1998a. Crop genetic resources from Ustica island (Italy): collecting and safeguarding. Plant Genet. Resour. Newsl. 116:12-17.

Laghetti G, Hammer K, Perrino P., 1996. Plant genetic resources in Pantelleria and Pelagie archipelago, Italy: collecting and conservation of local crop germplasm. FA0/IBPGR Plant Genet. Resour. Newsl. 108:17-25.

Laghetti G., Hammer K., Perrino P., 1998b. Presence, history and uses of Lavatera arborea L. (Malvaceae) on Linosa Island (Italy). Econ. Bot. 52:197-109.

Mace G.M., Cramer W., Diaz S., Faith D.P., Larigauderie A., Le Prestre P., Palmer M., Perrings C., Scholes R.J., Walpole M., Walther B.A., Watson J.E.M., Mooney H.A., 2010. Biodiversity targets after 2010. Curr. Opin. Environ. Sustain. 2:3-8.

Massa B., La Mantia T., 2010. The decline of ground-nesting birds in the agrarian landscape of Italy. Rev. Écol. (Terre Vie) 65:73-90.

Millennium Ecosystem Assessment, 2005. Ecosystem and Human WellBeing: Current State and Trends, Volume 1. In: R. Hassan, R.
Scholes and N. Ash (eds.) Island System. Chapter 23 (Wong et al.). Island Press, Washington, DC, USA, pp 663-679.

Pasta S., 2001. Contributi alla conoscenza botanica delle isole minori circumsiciliane. I. Sintesi aggiornata delle conoscenze botaniche sull'Isola di Lampedusa finalizzata alla conservazione delle sue emergenze floristico-vegetazionali. Naturalista Siciliano S. IV, XXV(suppl.):19-70.

Pasta S., La Mantia T., 2001. Note sul paesaggio vegetale delle isole minori circumsiciliane. I. Consorzi forestali e preforestali dell'Isola di Lampedusa (AG) ed effetto degli impianti artificiali sulla vegetazione naturale. Naturalista Siciliano S. IV, XXV(Suppl.):71-89.

Pasta S., La Mantia T., 2003. Note sul paesaggio vegetale delle isole minori circumsiciliane. II. La vegetazione pre-forestale e forestale nelle isole del Canale di Sicilia: dalla ricostruzione storica alla gestione futura. Ann. Accad. Ital. Sci. For. LI:77-124.

Pasta S., La Mantia T., 2006. Relazione tecnico-scientifica sullimpatto del pascolo sulle emergenze botaniche della R.N.O. "Isola di Lampedusa e Isola dei Conigli" (AG).

Pasta S., La Mantia T., 2008. Le specie vegetali aliene in alcuni SIC siciliani: analisi del grado di invasività e misure di controllo. In: G. Galasso, G. Chiozzi, M. Azuma and E. Banfi (eds.) Le specie alloctone in Italia: censimenti, invasività e piani di azione. Mem. Soc. It. Sci. Nat. Museo Civ. Stor. Nat. Milano 36:79.

Pasta S., Scuderi L., Marcenò C., Marcenò C., 2007a. Aggiornamento delle conoscenze botaniche sull'isola di Ustica (Tirreno meridionale). Atti del $102^{\circ}$ Congr. Società Botanica Italiana, Palermo, 26 29 settembre 2007), riassunti: 307.

Pasta S., La Mantia T., Rühl J., 2007b. Analisi del dinamismo della vegetazione in un'area di saggio permanente negli ex-pascoli dell'isola di Lampedusa (Canale di Sicilia). Atti del $102^{\circ}$ Congresso Società Botanica Italiana, Palermo, 26-29 settembre 2007, pp 271.

Raimondo F.M., Gianguzzi L., Ilardi V., 1994. Inventario delle specie "a rischio" nella flora vascolare nativa della Sicilia. Quad. Bot. Ambientale Appl. 3:65-132.

Ravanello C. 2007. Il vino a Lampedusa una possibile realtà. Storia di una sperimentazione.-Corriere vinicolo 46:14-15.

Rivas-Martínez S., 2004. Global bioclimatics (Clasificación Bioclimática de la Tierra). Avalable from: http://www.globalbioclimatics.org

Rühl J., 2003. Vascular plant diversity in abandoned vine and caper cultures of Pantelleria Island (Sicily) and conclusions for landscape conservation. Degree Diss., University of Greifswald, Germany.

Rühl J., 2007. Vegetation dynamics on abandoned terraces of Sicily: the course and driving factors of succession. PhD Diss., University of Greifswald, Germany. Available from: http://ub-ed.ub.uni-greifswald.de/opus/volltexte/2007/409/

Sferlazzo D., 2009. Analisi climatica. In: T. La Mantia, S. Pasta and J. Rühl (eds.) Quadro conoscitivo e proposte gestionali relative agli aspetti floristici, vegetazionali e agro-forestali. Piano di Gestione "Isole Pelagie" SIC ITA040002 "Isole di Lampedusa e Lampione" e ZPS ITA040013 "Arcipelago delle Pelagie. Area marina e terrestre".

Spahillari M., Hammer K., Gladis T., Diederichsen A., 1999. Weeds as part of agrobiodiversity. Outlook Agr. 28:227-232.

UNEP, 1998. Biodiversity resources in small island developing States. Available from: http://islands.unep.ch/dd98-7a5.html 